Innlegg på inntil 400 ord lastes opp i http://mc.manuscriptcentral.com/tidsskriftet.

Redaksjonen forbeholder seg retten til å foreta redaksjonelle endringer.

Forfattere av vitenskapelige artikler har automatisk tilsvarsrett (jf. Vancouver-gruppens regler).

\section{Nevropsykologiske tester ved slag}

I Tidsskriftet nr. 19/2009 bruker Jorunn Helbostad og medarbeidere en ny norsk studie til å belegge påstanden om at SINS (screeninginstrument for nevropsykologiske symptomer ved slag) egner seg godt til å fange opp vanlige kognitive svikttegn etter hjerneslag (1). I denne studien ble Sunnaas sykehus sin standard nevropsykologiske undersøkelse av slagrammede brukt som kontrast til tre lite omfattende og presumptivt tidsbesparende tester (ved siden av SINS dreide det seg om screeninginstrumentet Cognistat og «Klokketesten») (2). Selv om det ikke var tilsiktet, kan Helbostad og medarbeideres innlegg oppfattes som et argument mot å gjennomføre grundig nevropsykologisk undersøkelse av slagrammede generelt. Vi var medforfattere på denne studien, og ønsker å presisere at studien de viser til, konkluderte med at man bare med stor forsiktighet kunne trekke slutninger fra disse testene om hvilke kognitive områder som særlig var affisert (2).

I mange tilfeller er en enkel kognitiv screening med tester som SINS mest hensiktsmessig, og ytterligere testing er en unødig belastning for pasienten og lite formålstjenlig med tanke på ressursbruk. Ofte er det hensiktsmessig å starte med en enkel screening og så gå videre med mer sensitive metoder dersom det mistenkes svikt som screeningen ikke kan fange opp. Altfor mange må leve med usynlig kognitiv svikt, men har fått beskjed etter overfladisk testing om at det ikke er noen skade. Testing helbreder ikke kognitiv svikt, men kan gjøre det lettere for personen å tilpasse seg skaden og få forståelse fra andre. Verken å innføre raske skåringsverktøy som eneste alternativ eller å innføre omfattende nevropsykologiske metoder for alle, kan derfor anbefales. Fremdeles står dette fast: grundige utredninger må gjøres der det er indikasjon for det.

\footnotetext{
Anne-Kristine Schanke

Hilde Bergersen

Sunnaas sykehus

\section{Litteratur}

1. Helbostad JL, Saltvedt I, Strobel C et al. Skåringsverktøy i geriatri og rehabilitering. Tidsskr Nor Legeforen 2009; 129: 2020

2. Nøkleby K, Boland E, Bergersen $\mathrm{H}$ et al. Screening for cognitive deficits after stroke; a comparison of three screening tools. Clin Rehabil 2008; 12 1095-104.
}

\section{Akuttpsykiatri og legevakt}

\section{Tidsskriftet}

nr. 19/2009 er det

referert resultater

fra to «kvasieks-

perimentelle»

undersøkelser

hvor hovedfor-

målet i begge var

å redusere antal-

let akuttinnleg-

gelser i den

lokale akuttpsy-

kiatriske sykehusavdeling $(1,2)$. Virkemidlet var forskjellig.

I den ene undersøkelsen var det opprettet en krisepost på døgnenheten ved Drammen distriktspsykiatriske senter. I den andre fungerte et akutteam bemannet med lege og tre psykiatriske sykepleiere med basis i Notodden/Seljord DPS.

Forutsetningen i begge undersøkelser var at henvendelser skulle komme via primærlege de første fem ukedager innen kl 1530 og ikke etter kl 15 fredag. Det var også noe usikkerhet om primærlegene var godt nok orientert.

Som gammel legevaktlege vet jeg at «livskrisehendelser» og mer alvorlige psykiske lidelser har en tendens til å eksponere seg om kvelden/natten og i helgene, og de kommer ikke på bestilling. Enhver legevaktlege vet hvor tidkrevende akuttpsykiatrien er, særlig til disse tider, og gjerne til fortrengsel for andre somatiske akuttmedisinske oppgaver.

Derfor hilser vi velkommen heldøgnsbemannede akuttpsykiatriske kriseteam med basis i distriktspsykiatrisk senter med egen krisepost og kvalifisert døgnbemanning. Dette vil utvilsomt føre til mindre innleggelsespress på den lokale akuttpsykiatriske avdeling for «livskriselidelser». Den generelle legevaktlegen vil føle lettelse ved denne avlastningen og derved kunne gjøre en bedre jobb innen det akutte somatiske feltet.

Begge «kvasieksperimentelle» undersøkelser førte ikke til forventede resultater pga. de nevnte metodologiske svakheter. Det var imidlertid en tankevekkende begynnelse.

\section{Per Steinar Steinsvoll} Sel

\section{Litteratur}

1. Bergerud T, Møller P, Larsen F. Krisepost ved distriktspsykiatrisk senter reduserer ikke akuttinnleggelser i sykehus. Tidsskr Nor Legeforen 2009; 129: 1973-6.
2. Kolbjørnsrud O-B, Larsen F, Elbert G. Kan psykiatrisk akutteam redusere bruk av akuttplasser ved sykehus? Tidsskr Nor Legeforen 2009; 129: 1991-4.

\section{0.-B. Kolbjørnsrud svarer:}

Per Steinar Steinsvoll påpeker at «livskrisehendelser» og mer alvorlige psykiske lidelser har en tendens til å eksponere seg utenom vanlig arbeidstid. Han hevder at dette vil kunne fortrenge andre somatiske akuttmedisinske oppgaver for legevaktlegen. Han mener derfor at man bør opprette heldøgnsbemannede akuttpsykiatriske kriseteam med basis i distriktspsykiatrisk senter (DPS) med egen krisepost og kvalifisert døgnbemanning.

Notodden/Seljord DPS har opptaksområde på 45000 innbyggere. Det er godt utbygd og ivaretar de oppgavene som myndighetene forutsetter at et slikt senter skal ha. Vi har god legebemanning også på døgnenhetene. Senteret har akutt- og krisetjenester. Denne tjenesten er videreutviklet etter prosjektperioden i 2004. Vi er lett tilgjengelige for kommunehelsetjenesten på dagtid blant annet gjennom akutteam i Notodden og i Seljord. Etter ordinær arbeidstid er vakthavende psykiater ved senteret tilgjengelig for legevaktlegen på telefon. Vi bruker psykiatrisk akuttavdeling mindre enn resten av fylket.

Akutt- og krisetjenesten ved distriktspsykiatrisk senter skal ikke erstatte primærhelsetjenestens legevaktfunksjon for psykiatriske pasienter, men skal være lett tilgjengelig dersom primærlegen har behov for hjelp fra spesialisthelsetjenesten. Utfordringen vår er å bruke ressursene på en hensiktsmessig måte. Oppgavefordelingen mellom et slikt senter og sentraliserte sykehusenheter er klart definert i DPS-veilederen. Innsatsen bør innrettes slik at pasienter ikke legges inn på psykiatrisk akuttavdeling dersom de kan tas hånd om ved senteret. Døgnenheter med akuttsenger og kvalifisert personell skal være en del av distriktspsykiatrisk senter. I Telemark skal psykiatrisk akuttavdeling i Skien ivareta øyeblikkelig hjelp-funksjonen etter loven, og denne avdelingen har ressurser til å kunne ta imot pasienter til alle døgnets tider.

I løpet av de ti første månedene i 2009 var det 123 innleggelser ved psykiatrisk akuttavdeling fra vårt opptaksområde. 66 av innleggelsene skjedde på kveldstid, om natten og i helger. Akuttavdelingens 
personale gir uttrykk for at dette er innleggelser som er relevante for akuttavdelingen. Vi kan finne nærmere ut om dette ved blant annet å se på pasientenes symptom- og funksjonsnivå (GAF-skår). Jeg mener at det ikke er ressursmessig fornuftig å ha heldøgnsbemannede akutteam ved distriktspsykiatrisk senter. Vår beredskap i dag tar hånd om de aller fleste «livskrisehendelser». De aller fleste pasientene som legges inn ved psykiatrisk akuttavdeling fra vårt opptaksområde har behov for denne avdelingens rammer.

Ole-Bjørn Kolbjørnsrud

Notodden/Seljord DPS

\section{Protonpumpehemmere og reseptfrihet}

Helge L. Waldum uroer seg i Tidsskriftet nr. 21/2009 for protonpumpehemmeres langtidsbivirkninger, og hevder de ikke bør selges reseptfritt (1).

Som kommentar til Waldums uro for bivirkninger kan nevnes at det kliniske utviklingsprogrammet av substansen pantoprazol omfatter 250 studier på 80500 pasienter. Den gunstige bivirkningsprofilen kan interesserte lese om i detalj. Bivirkningsdata rapporteres offentlig under den korte produktoversikten på Statens legemiddelverks hjemmeside og ekspertrapporten (EPAR) på hjemmesiden til European Medicines Agency (2). Waldum konstaterer at tidsbegrensede pasientstudier ikke kan avsløre langtidsbivirkninger, men det finnes naturligvis et regelverk rundt langtidsoppfølging av legemidler. Etter lanseringen av pantoprazol er 733000 behandlinger gjennomgått i de såkalte Post-Authorisation Safety Studies (2). Hensikten med disse er å oppdage nettopp uvanlige bivirkninger. Dessuten følger Nycomed myndighetenes krav om en omfattende oppfølging med legemiddelovervåking. Siden lanseringen av pantoprazol i 1994 har 665 millioner pasienter på verdensbasis fått pantoprazolbehandling. European Medicines Agency har ikke identifisert noen nye sikkerhetsrisikoer siden det.

Pantoprazol har vært reseptfritt i Sverige siden februar 2000. Det har ikke vært tegn til at reseptfriheten har bidratt til feil bruk eller påvirkning av legemidlets sikkerhetsprofil (2). Nycomed har da også lagt vekt på at pasientene skal informeres i pakningsvedlegget om at man må kontakte lege om symptomene ikke forbedres i løpet av to uker, samt at de ikke skal ta tablettene i mer enn fire uker.

Det er derfor etter vårt skjønn ingen grunn til å tvile på at det er trygt å tilby norske pasienter muligheten til å bruke pantoprazol reseptfritt for reflukssymptomer som reduserer livskvaliteten.
Mikael Gellerfors

Nycomed Pharma

\section{Litteratur}

1. Waldum HL. Protonpumpehemmere bør ikke selges reseptfritt. Tidsskr Nor Legeforen 2009: 129: 2263

2. European Medicines Agency www.emea.europa eu/humandocs/PDFs/EPAR/Somac_Control/ H-1098-en6.pdf (15.12.2009).

\section{Risikoskår og TIA-pasienter}

I vår artikkel

i Tidsskriftet nr.

22/2009 presen-

terte vi ABCD-

skår som et red-

skap til å risikostratifisere TIApasienter, slik at lavrisikopasienter kan identifiseres og tilbys rask

poliklinisk utred-

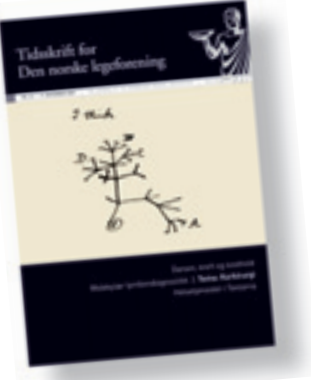

ning og behandling og de med høy risiko innlegges direkte i sykehus (1). I artikkelen er skår $\geq 5$ anført som beslutningsgrense mellom lav- og høyrisikopasienter. Dette kan innebære at enkelte med skår 4 ikke får rask nok vurdering, noe som best kan løses ved umiddelbar innleggelse i sykehus. Ved å benytte skår $\geq 4$ som beslutningsgrense vil man kunne unngå dette. Det finnes internasjonale retningslinjer som benytter $\geq 5$ som beslutningsgrense (2), men i England hvor ABCD-skåren er mest utprøvd, er grensen satt til $\geq 4$ (3). Risikoen for å få et manifest hjerneslag de første dagene etter et TIA-anfall er $<1 \%$ hos pasienter med lavere skår enn 4, og. for de fleste pasienter i denne kategorien vil derfor en rask poliklinisk utredning være et trygt og godt alternativ til akutt innleggelse $(3,4)$. Vi vil imidlertid understreke at risikoskårer bare er veiledende og må suppleres med klinisk skjønn, også ved lav risiko. Klinisk praksis er individbasert, også i denne sammenhengen.

\section{Hanne Ellekjær \\ Torbjørn Dahl \\ Trondheim}

\section{Litteratur}

1. Dahl T, Ellekjær H. Carotisstenose - utredning og behandling. Tidsskr Nor Legeforen 2009; 129: 2374-7.

2. Stroke Foundation. www.strokefoundation.com au/images/stories/healthprofessionals/clinical $\% 20$ guidelines $\% 20$ for $\% 20$ acute $\% 20$ stroke $\% 20$ management.pdf (15.12.2009).

3. The National Collaborating Centre for Chronic Conditions. www nice.org.uk/nicemedia/pdf/ CG68FullGuideline pdf (15.12.2009).

4. Johnston SC, Rothwell P, Nguyen-Huynh M et al. Validation and refinement of scores to predict very early stroke risk after transient ischaemic attack. Lancet 2007: 369: 283-92.

\section{RETTELSE}

Overdosestatistikk et komplisert regnskap

Thomas Clausen, Ingrid A. Havnes, Helge Waal Tidsskr Nor Legeforen 2009; 129: 2233-6

I ovennevnte artikkel i Tidsskriftet nr. 21/2009 s. 2234 var det feil i figurteksten til figur 1. Figuren og tabellen bygger på politistatistikken slik denne ble publisert 30.4. 2008 og på tidligere SIRUS-rapporter. Politistatistikken er senere korrigert slik det er beskrevet i artikkelen. Det presiseres derfor at det er de korrigerte tallene som skal brukes videre. Disse finnes i rapporten Rusmidler i Norge 2008 (www.sirus.no/internett/alkohol/publication/ 464.html) og RusStat (http://statistikk.sirus. no/sirus/

\section{RETTELSE}

Overføring av spesialistgodkjenning

Einar Skoglund, Brit Torill Gutbier

Tidsskr Nor Legeforen 2009; 129: 2520

I Tidsskriftet nr. 23/2009, på side 2520, skal mellomtittelen i midtspalten være:

Nordisk overenskomst

\section{Tilsvarsrett}

Tidsskriftet praktiserer tilsvarsret i henhold til Vancouver-gruppens regler (www.icmje.org/ publishing_5correspond.html]. Dersom vitenskapelige artikler kommenteres i spalten, får artik kelforfatterne mulighet til å svar i samme nummer. Slik automare tilsvarsrett gjeld. Slik automatisk tere av vit gjelder kun for forfatDen gjelder imapelige artikler. debatten imidlertid ikke dersom Brev til redtsetter i spalten eksempel publisen, dvs. hvis det for til det første tilsvaret. 